\title{
Determination of Groundwater Vulnerability Using the DRASTIC Method in Ouargla Shallow Aquifer (Algerian Sahara)
}

\author{
Adel Satouh ${ }^{1}$, Bouselsal Boualem ${ }^{2 *}$, Smaine Chellat ${ }^{3}$, Lahcen Benaabidate ${ }^{4}$ \\ 1 Laboratory of Saharan Geology, Department of Earth and Universe Sciences, University of Kasdi Merbah, \\ Route de Ghardaia, BP 511, 30000, Ouargla, Algeria \\ 2 Laboratory of Underground Reservoirs: Oil, Gas and Aquifers, Department of Earth and Universe Sciences, \\ University of Kasdi Merbah, Route de Ghardaia, BP 511, 30000, Ouargla, Algeria \\ 3 Laboratory of Environmental Geology, University of Constantine 1, Route Ain El Bey Zouaghi Slimane \\ Constantine, 25000, Algeria \\ ${ }^{4}$ Laboratory of Functional Ecology and Environmental Engineering, Faculty of Sciences and Techniques, \\ University of Sidi Mohammed Ben Abdellah, Fez, 30000, Morocco \\ * Corresponding author's email: bousboualem@gmail.com
}

\begin{abstract}
Groundwater is the main source for many uses around the city of Ouargla. In this study, the DRASTIC method was used to assess the vulnerability of the groundwater aquifer. Seven hydrogeological parameters of the model (D water depth, R efficient charging, A aquifer type, S soil type, T topography, I unsaturated zone and C hydraulic conductivity) were measured and mapped. The intrinsic vulnerability map of the shallow aquifer, using the DRASTIC method, shows a high to very high vulnerability to pollution; $91.6 \%$ of the study area has high vulnerability, $8.4 \%$ of it has very high vulnerability. The comparison of the DRASTIC maps with the land use map illustrates that the agglomerations and irrigated areas are the most vulnerable areas to pollution, due to the low depth of the aquifer and the infiltration of significant domestic and irrigation wastewater. The results show that the relationship coefficient between the DRASTIC index and nitrate concentration is $\mathrm{R}=0.73$. This indicates that the groundwater vulnerability mapping by using the DRASTIC method can be applied for sensible groundwater resources management and land-use planning in the study area.
\end{abstract}

Keywords: Ouargla, shallow aquifer, vulnerability, DRASTIC, land-use.

\section{INTRODUCTION}

The region of Ouargla has long suffered from the shallow aquifer water upwelling phenomena. This increase is largely due to the overexploitation of deep aquifers to meet the needs of irrigation and drinking water supply, and the direct discharge into the shallow aquifer of wastewater without treatment. In addition, natural constraints, such as the almost flat topography and the absence of an effective natural outlet, have accentuated the phenomenon of upwelling.

In the investigated area, numerous sources of groundwater contamination have been identified (Zeddouri, 2008; Bouselsal, 2017), such as the infiltration of domestic wastewater under the settlements and the excessive use of fertilizers in the agricultural areas. These multiple pollutants alter the quality of groundwater, if conditions are favorable. This paper presents a pollution vulnerability assessment using the DRASTIC approach. The aim was to create an effective model for the sustainable management and protection of groundwater resources in the study area.

\section{PRESENTATION OF THE STUDY AREA}

The Ouargla basin is located in a depression of Oued Miya (Algerian Sahara), delimited 
by UTM coordinates: $\mathrm{X}=710000 / 730000 \mathrm{E}$ and $\mathrm{Y}=3530000 / 3600000 \mathrm{~N}$. The surface of the study area (Fig. 1) is approximately $700 \mathrm{~km}^{2}$ and it has a population of about 297,696 inhabitants. The climate of the region is Saharan type, characterized by weak and irregular rainfall $(62.40 \mathrm{~mm} /$ year $)$. There is a significant difference in temperature with a monthly average of about $24.74^{\circ} \mathrm{C}$ and a very high evaporation (2758.80 mm) (NOM, 2007-2018).

The Ouargla basin is part of the Saharan platform (Busson, 1970; Slimani et al., 2017). The latter is an asymmetric syncline emerged by sediments of several thousand meters, in the center of the basin, ranging from Primary to Quaternary.

At the surface of the investigated area, only Quaternary and Mio-Pliocene geologic layers are visible. The well data show that the geological trainings contain three aquifer layers (UNESCO, 1972; OSS, 2003). These are, from bottom to top (Fig. 2): the intercalary continental (CI) aquifer, the complex terminal (CT) aquifer and the shallow aquifer. The latter is made up of detrital formations of Quaternary age represented by sands, sandstones and gravels with the presence of gypsum.

The piezometric map established in May 2017 (Fig. 3) shows that the direction of flow of the water table is from South-West to NorthEast. The isohypses curves are relatively close with a concavity oriented to the South-West; its concavities indicating a surplus of water resulting from the infiltration of wastewater under the city of Ouargla and the infiltration of irrigation water under the agricultural areas (Bour Elhaicha and Ain Moussa).

\section{MATERIALS AND METHODS}

\section{DRASTIC model}

The DRASTIC method (Aller et al., 1987; Bouselsal et al., 2015) is a method with super

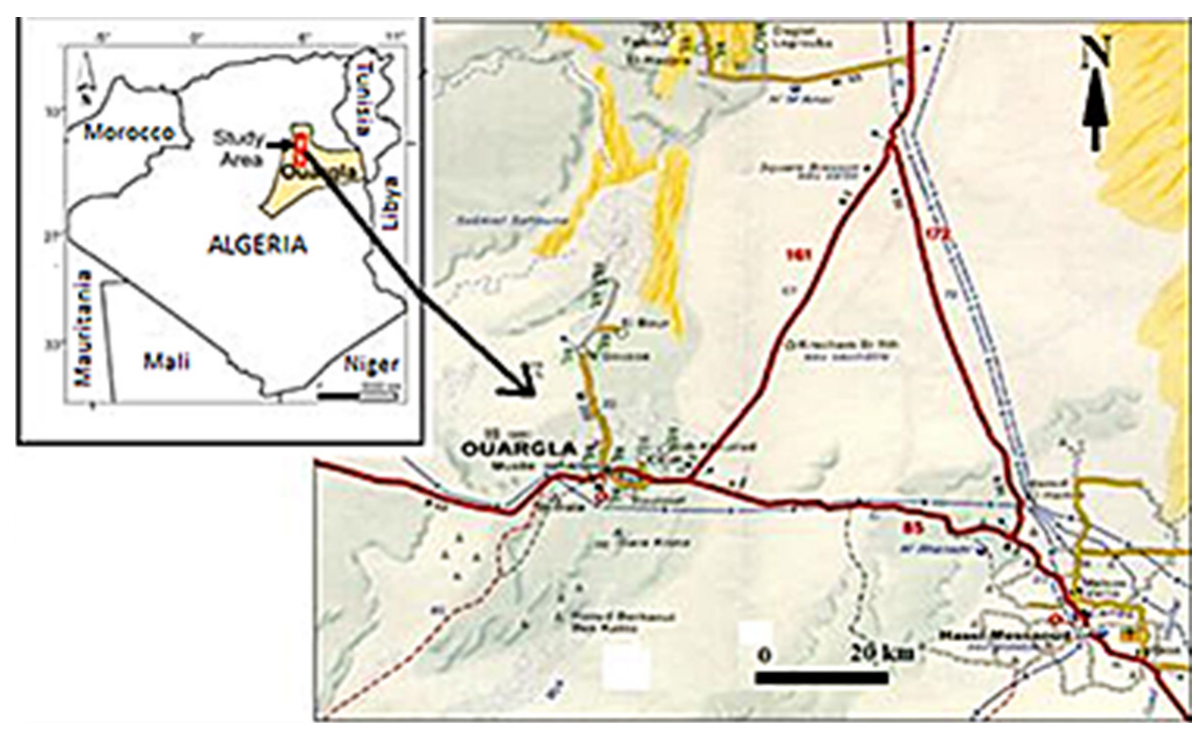

Figure 1. Geographic situation of the study area

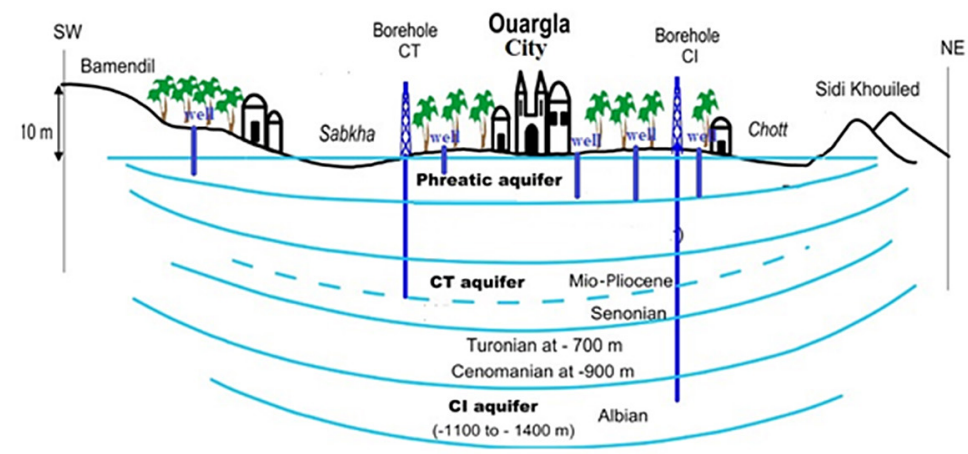

Figure 2. Schematic hydrogeological section of the Ouargla basin 
imposable parameters and indices. It was developed by the US Environmental Protection Agency (EPA). The method considers seven parameters to estimate the groundwater vulnerability, namely D (water depth), R (efficient charging), A (aquifer type), S (soil type), T (topography), I (unsaturated zone), and C (hydraulic conductivity) of the aquifer medium.

Each parameter is subdivided into ranges that are assigned different scores on a scale of 1 to 10 (Aller et al., 1987). The weight multipliers vary between 1 and 5, the latter illustrating the importance of the parameter in the contaminant transport and attenuation process (Table 1).

The calculation of the DRASTIC Index (DI) for each hydrogeological unit is obtained by summing the products of each index by its weight, using the following formula:

$$
\begin{aligned}
& I D=D p \times D c+R p \times R c+A p \times A c+ \\
& +S p \times S C+T p \times T c+I p I c+C p \times C c
\end{aligned}
$$

Engel et al. (1996) proposed the classification of the vulnerability index values into four classes (Table 2).

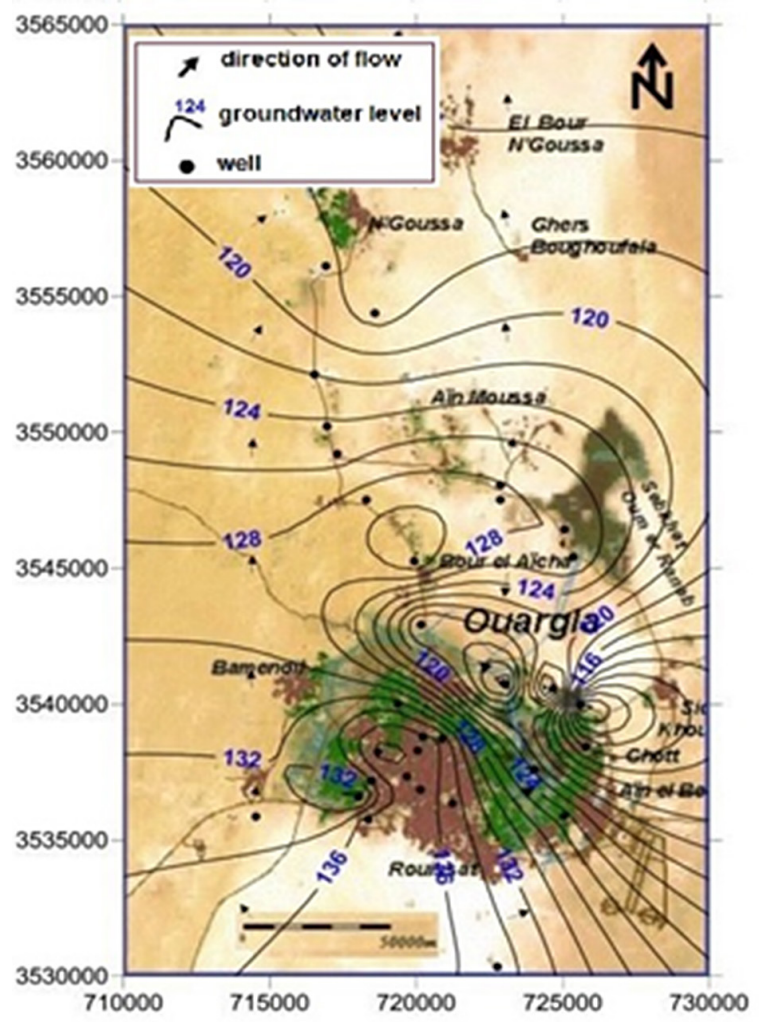

Figure 3. Piezometric map of the Phreatic aquifer
Table 1. Ratings given to the parameters of the DRASTIC method and their weighting

\begin{tabular}{|c|c|c|c|}
\hline Parameter & Parameter Value/Types & Ranges & Weights \\
\hline \multirow{8}{*}{$\begin{array}{l}\text { D } \\
\text { Depth to } \\
\text { water }\end{array}$} & $>30 \mathrm{~m}$ & 1 & \\
\hline & $30-22.5 m$ & 2 & \\
\hline & $22.5-15 m$ & 3 & \\
\hline & $9-15 m$ & 5 & 5 \\
\hline & $4.5-9 m$ & 7 & \\
\hline & $3-4.5 m$ & 8 & \\
\hline & $1.5-3 m$ & 9 & \\
\hline & $<1.5 \mathrm{~m}$ & 10 & \\
\hline \multirow{5}{*}{$\begin{array}{l}\mathrm{R} \\
\text { Net } \\
\text { recharge }\end{array}$} & $0-50 \mathrm{~mm}$ & 1 & \\
\hline & $50-100 \mathrm{~mm}$ & 3 & \\
\hline & $100-175 \mathrm{~mm}$ & 6 & 4 \\
\hline & $175-225 \mathrm{~mm}$ & 8 & \\
\hline & $>225 \mathrm{~mm}$ & 9 & \\
\hline \multirow{10}{*}{$\begin{array}{l}\text { A } \\
\text { Aquifer } \\
\text { media }\end{array}$} & Silt/Clay & 1 & \\
\hline & Shale & 2 & \\
\hline & Metamorphic/lgneous & 3 & \\
\hline & $\begin{array}{l}\text { Sand and gravel with } \\
\text { signifcant silt and clay }\end{array}$ & 4 & \\
\hline & Shale in sequence & 6 & \\
\hline & Sandstone & 6 & 3 \\
\hline & Massive limestone & 6 & \\
\hline & Sand and gravel & 8 & \\
\hline & Basalt & 9 & \\
\hline & Karst limestone & 10 & \\
\hline \multirow{9}{*}{$\begin{array}{l}\text { S } \\
\text { Soil media }\end{array}$} & Unfissured clay & 1 & \\
\hline & Siltyclay & 3 & \\
\hline & Limon silteux & 4 & \\
\hline & Silt & 5 & \\
\hline & Siltysand & 6 & 2 \\
\hline & $\begin{array}{l}\text { Clay, aggregates } \\
\text { or slopes }\end{array}$ & 7 & \\
\hline & Sand & 9 & \\
\hline & Gravel & 10 & \\
\hline & $\begin{array}{l}\text { Soil slightly thick } \\
\text { or absent }\end{array}$ & 10 & \\
\hline \multirow{7}{*}{$\begin{array}{l}\text { T } \\
\text { Topography }\end{array}$} & $>18 \%$ & 1 & \\
\hline & $12-18 \%$ & 3 & \\
\hline & $10-12 \%$ & 5 & \\
\hline & $8-10 \%$ & 7 & \\
\hline & $6-8 \%$ & 8 & 1 \\
\hline & $2-6 \%$ & 9 & \\
\hline & $0-2 \%$ & 10 & \\
\hline \multirow{9}{*}{$\begin{array}{l}\text { I Impact of } \\
\text { vadose } \\
\text { zone }\end{array}$} & Silt and Clay & 1 & \\
\hline & Shale & 3 & \\
\hline & Limestone & 6 & \\
\hline & Sandstone & 6 & \\
\hline & $\begin{array}{l}\text { Lite limestone, } \\
\text { sandstone, shale }\end{array}$ & 6 & 5 \\
\hline & $\begin{array}{l}\text { Sand and gravel with silt } \\
\text { and clay }\end{array}$ & 6 & \\
\hline & Sand and gravel & 8 & \\
\hline & Basalt & 9 & \\
\hline & Karst limestone & 10 & \\
\hline \multirow{6}{*}{$\begin{array}{l}\text { C } \\
\text { Hydraulic } \\
\text { conductivity }\end{array}$} & $4.7 \cdot 10^{-5}-4.7 \cdot 10^{-5} \mathrm{~m} / \mathrm{s}$ & 1 & \\
\hline & $4.7 \cdot 10^{-5}-14.7 \cdot 10^{-5} \mathrm{~m} / \mathrm{s}$ & 2 & \\
\hline & $14.7 \cdot 10^{-5}-32.9 \cdot 10^{-5} \mathrm{~m} / \mathrm{s}$ & 4 & 3 \\
\hline & $32.9 \cdot 10^{-5}-4.7 \cdot 10^{-4} \mathrm{~m} / \mathrm{s}$ & 6 & \\
\hline & $4.7 \cdot 10^{-4}-9.4 \cdot 10^{-4} \mathrm{~m} / \mathrm{s}$ & 8 & \\
\hline & $>9.4 \cdot 10^{-4} \mathrm{~m} / \mathrm{s}$ & 10 & \\
\hline
\end{tabular}
(Lallemand-Barrès, 1994) 


\section{Measures and preparation of the data:}

The elaboration of the vulnerability map requires a certain amount of data. According to Table 3, the types of data were obtained from different sources.

\section{Validation Vulnerability map}

The aquifer vulnerability method requires validation (Al-Amoush et al., 2010; Bachaer et al., 2017; Leone et al., 2007). To this end, this study used Pearson's correlation (Fink et al., 1995) to assess the relationship between the DRASTIC model and actual pollution data (nitrate values in water). Indeed, the nitrate values are used as an indicator of anthropogenic pollution when the nitrate concentration exceeds $10 \mathrm{mg} / \mathrm{l}$ (Ghazavi et al., 2015).

\section{RESULTS AND DISCUSSIONS}

\section{Vulnerability settings}

The study of the seven vulnerability parameters was carried out in this work and the results indicate that the water depth is a critical parameter. It defines the width of the materials through which water infiltrates to meet groundwater and reflects the vertical distance between the ground surface and the water table (Rahman, 2008). This parameter is assigned a maximum weight of 5 in the DRASTIC model (Aller et al., 1987). The depth of the aquifer varies between 1.5 and $15 \mathrm{~m}$ (Fig. 4), increasing from East to West. According to the DRASTIC classification, there are five depth classes, with scores ranging from 10 to 6 .

Next, the results show that recharge of an aquifer can have several origins. Each of these must be addressed separately to estimate recharge (Thomas et al., 2006). These origins are direct contribution by precipitation (effective rainfall), re-infiltration due to irrigation, and urban charging. The water balance of the study

Table 2. Vulnerability DRASTIC Class (Engel et al 1996)

\begin{tabular}{|l|c|}
\hline \multicolumn{1}{|c|}{ Vulnerability class } & vulnerability index \\
\hline low & $<100$ \\
\hline Moderate & 101 to 140 \\
\hline High & 141 to 200 \\
\hline Very high & $>200$ \\
\hline
\end{tabular}

area shows that the easily usable reserve is empty during the eleven months of the year, generated by low precipitation and high evaporation. In this study, the recharge areas were defined from the interpretation of the satellite image and the land-use map. The calculation of urban wastewater recharge was based on water consumption by the population of urban areas and the ratio of water consumed to wastewater estimated at 0.8 (Bouselsal et al., 2015). Irrigation recharge was estimated from the data provided by the Directorate of Agriculture of Ouargla.

As for the effective recharge map (R), it defines two recharge classes (Fig. 5). In Class 1, the recharge is greater than $225 \mathrm{~mm}$. In agricultural areas, it is the result of irrigation water infiltration and in urban areas, it is the result of domestic wastewater and irrigation water infiltration. The score assigned to this class is equal to 9. In Class 2 , the recharge is less than $50 \mathrm{~mm}$. This class is represented by desert areas as well as uninhabited and unexploited places. Due to very arid climatic conditions, the recharge is very low or even zero. The score assigned to this class is equal to 1 .

The geo-electric section (Fig. 6) shows that the lithology of the aquifer consists of sand and gravel with the presence of gypsum and tuff (limestone concretion) levels in the chotts and sebkhas. The score assigned to this class is equal to 8 .

The unsaturated zone is defined by the interface between the ground surface and the piezometric surface of the water table. The core drillings, as well as the piezometer logs (Fig. 7), identified the presence of three classes of geological profiles. The score attributed for this parameter is 8 .

Table 3. Basic data used for the vulnerability calculation

\begin{tabular}{|l|l|}
\hline \multicolumn{1}{|c|}{ Parameter } & \multicolumn{1}{c|}{ Main sources of information } \\
\hline D : Depth to water & $\begin{array}{l}\text { A piezometric measurement company } \\
\text { may 2017 }\end{array}$ \\
\hline R : Net recharge & $\begin{array}{l}\text { Hydraulic balance } \\
\text { Analysis of the land use map }\end{array}$ \\
\hline A : Aquifer media & $\begin{array}{l}\text { Borehole data analyze } \\
\text { Geophysical data }\end{array}$ \\
\hline S : Soil media & $\begin{array}{l}\text { data from the Directorate of Agriculture } \\
\text { Particle size curves established by } \\
\text { LTPS }\end{array}$ \\
\hline T: Topography & Remote sensing imagery \\
\hline $\begin{array}{l}\text { I: Impact of } \\
\text { vadose zone }\end{array}$ & $\begin{array}{l}\text { Geologic map. } \\
\text { Borehole data analyze }\end{array}$ \\
\hline $\begin{array}{l}\text { C : Hydraulic } \\
\text { conductivity }\end{array}$ & $\begin{array}{l}\text { The interpretation of pumping tests } \\
\text { Data provided by ANRH and LTPS }\end{array}$ \\
\hline
\end{tabular}




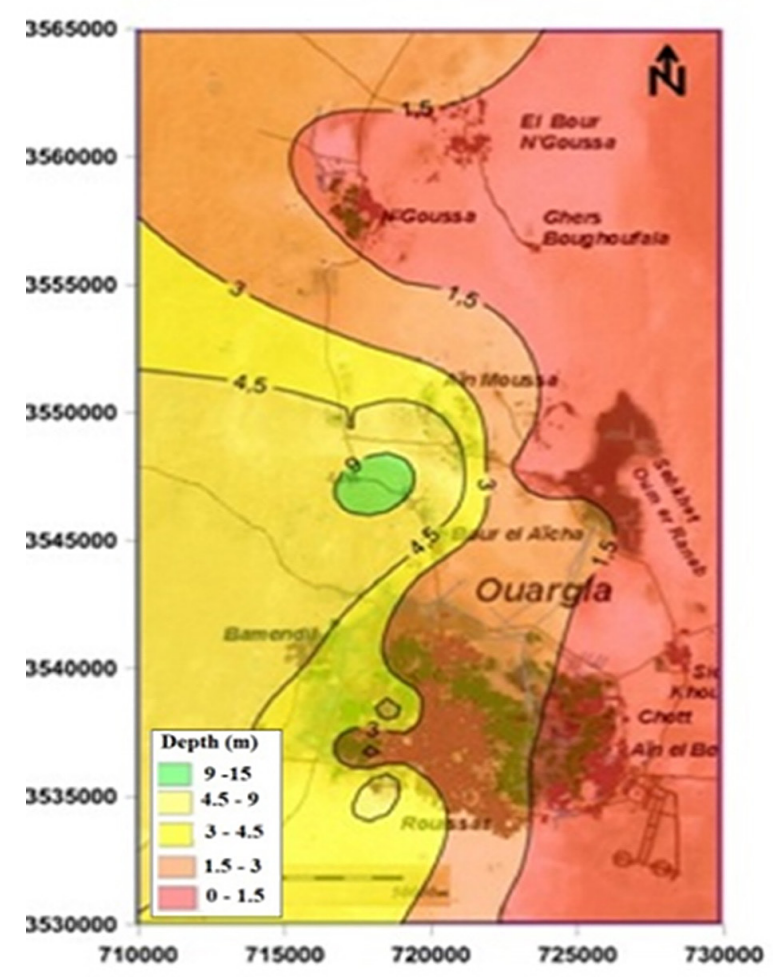

Figure 4. Depth to water level map

Class A: This is the most widespread class, representing $75 \%$ of the area, where the following can be distinguished:

- a first layer, the thickness of which varies from 1 to $2 \mathrm{~m}$, made up of fine to medium sand slightly gypsum with a consistency of medium compactness;

- a second layer made up of compact clayey sand, the thickness of which varies between 5 and $15 \mathrm{~m}$.

Class B: characterizes the chotts and sebkhas, where the following can be distinguished:

- very salty gypsum crusts whose thickness varies from 1 to $2 \mathrm{~m}$;

- silty sands with a passage of tuff.

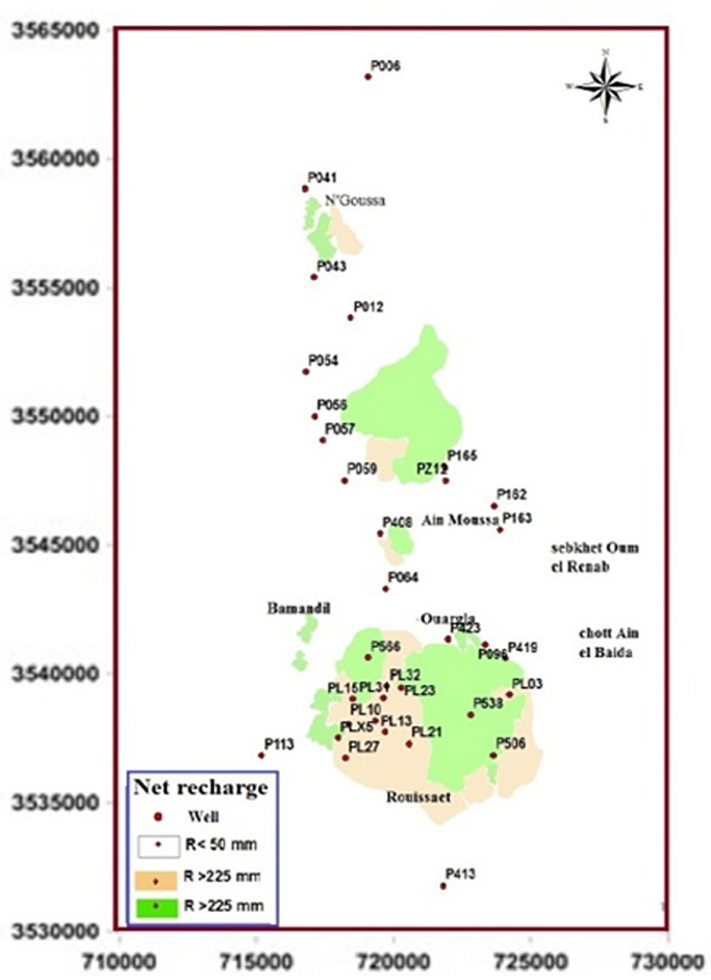

Figure 5. Net recharge map

Class C: characterizes the slopes of the basin and the Mio-Pliocene plateau, where where the following can be distinguished:

- detrital material consisting of consolidated sandstone (glacis) and gypsum-poor loamy sand, with a thickness greater than $10 \mathrm{~m}$;

- coarse and compact sand.

The amount of recharge and method of pollutant purification is also influenced by the nature and thickness of the soil (Lee, 2003). Soil is the top, weathered layer that supports biological processes. It plays a critical role in determining the amount of water that infiltrates the soil and in controlling the rate at which contaminants pass

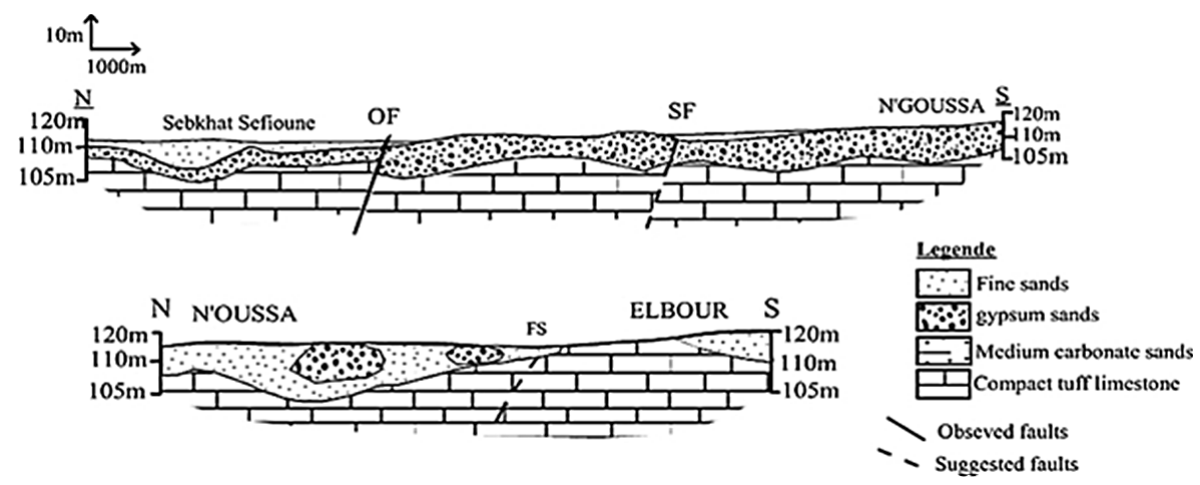

Figure 6. Geo-electric cut through sebkhat Safioune and N'Goussa 


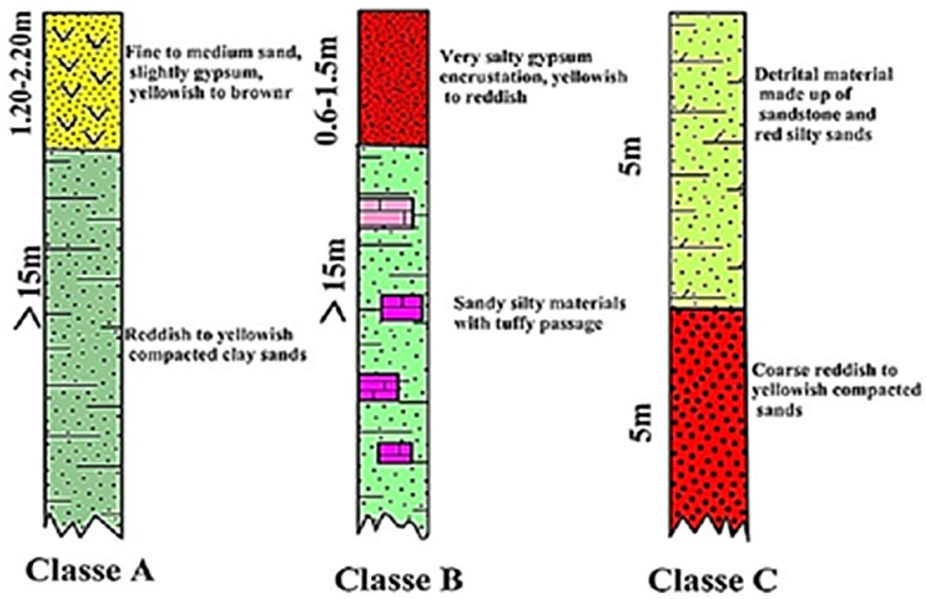

Figure 7. Lithology of the unsaturated zone of Phreatic aquifer

vertically through the vadose region. The description of the constituent soils of the Ouargla region is dominated by sands. The score assigned to this class is equal to 9 .

In the DRASTIC model, topography is expressed as slope. In hydrological modeling and water quality research, topography is very important. The low slope retains water for extended periods of time, which promotes water infiltration and thus increases the risk of groundwater pollution (Malik and Shucla, 2019). In this study, the SRTM data was processed in ArcGIS for slope extraction. The slope map established by given values varies between $0 \%$ and $18 \%$ (Fig. 8); it increases in the eastern part. According to the DRASTIC classification, there are five dominant slope classes, with scores ranging from 10 to 5 .

With respect to hydraulic conductivity, it controls the rate of groundwater flow in the saturated zone and thus the rate of migration of a pollutant. The average permeability coefficient of the aquifer based on the data provided by ANRH and LTPS and interpretation of pumping tests ranges from $4.7 \times 10^{-4} \mathrm{~m} / \mathrm{s}$ to $5.6 \times 10^{-4} \mathrm{~m} / \mathrm{s}$. Only one permeability class was determined with a score of 8 .

\section{Intrinsic vulnerability}

The indices evaluated by using the DRASTIC method (Engel et al., 1996) range from 151 to 208 and thus represent two classes that constitute the current map (Fig. 9). These are distributed as follows:

- very high vulnerability class; it covers $58.8 \mathrm{~km}^{2}$ or $8.4 \%$ of the area of the study region, it is located in the southeast of the area investigated. In areas with a low water table, due to upwelling water resulting from water infiltration under built-up areas and agricultural areas to the southeast of the study area;

- high vulnerability class; it occupies an area of $641.2 \mathrm{~km}^{2}$ or $91.6 \%$ of the total area. This class is located in the rest of the study area, mainly favored by the low piezometric level depth as well as the lithology of the saturated zone and unsaturated zone.

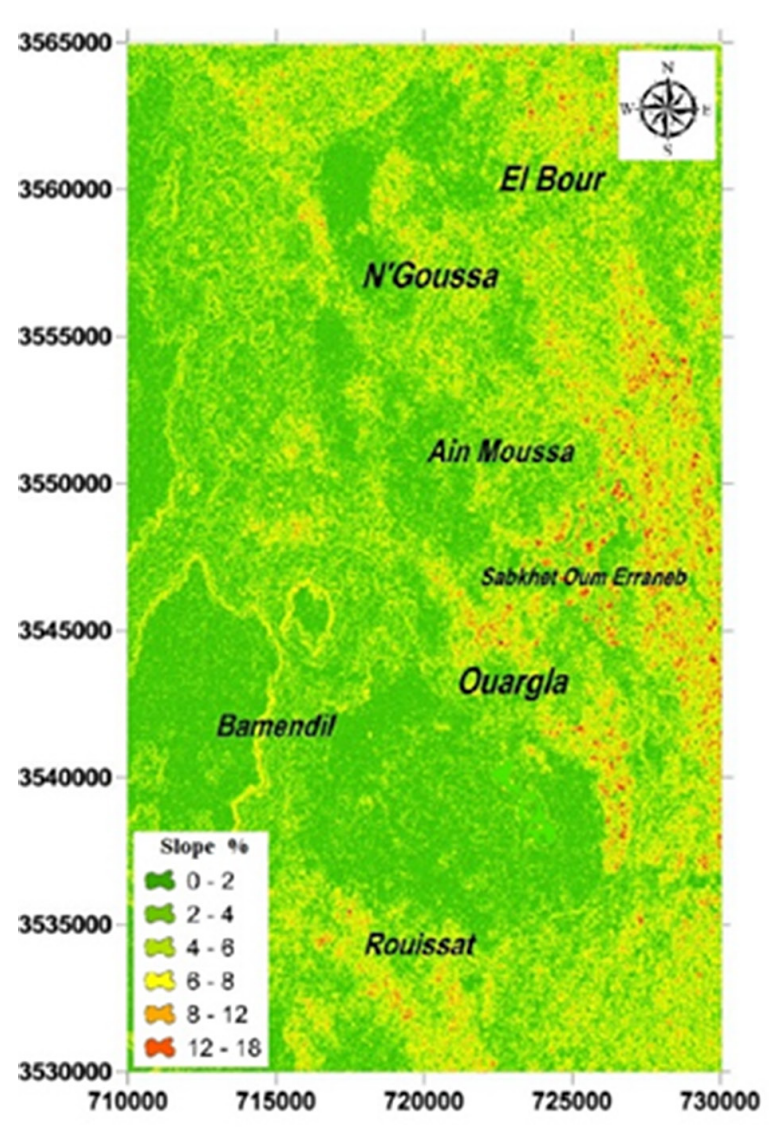

Figure 8. Slope map 


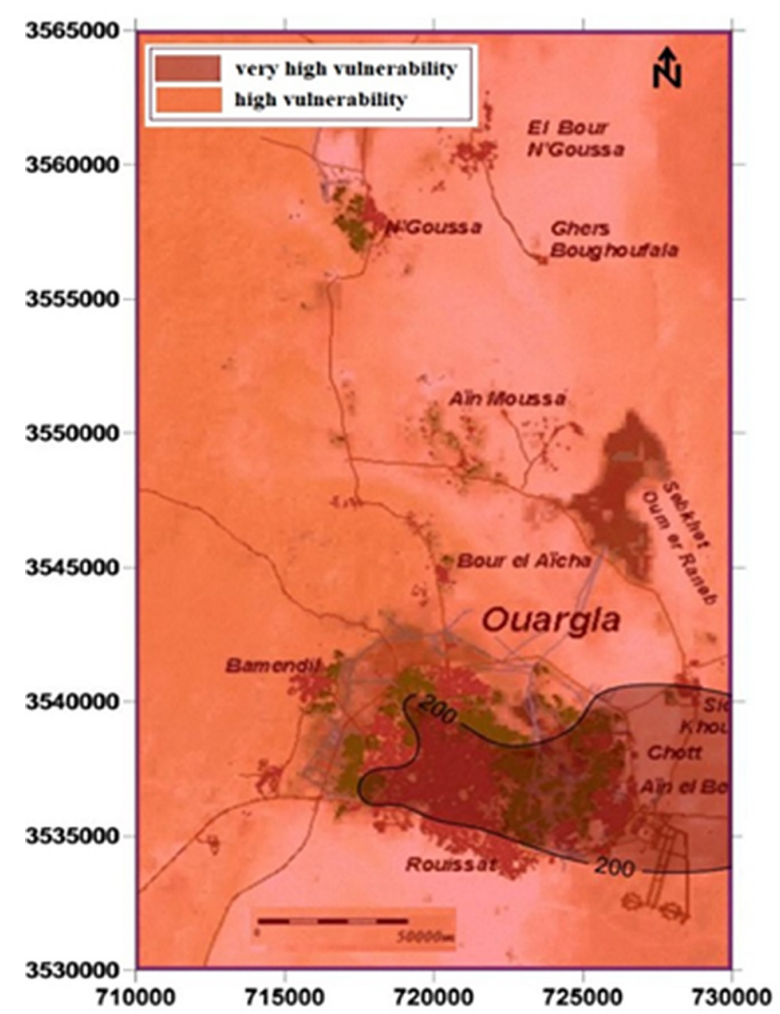

Figure 9. DRASTIC vulnerability map of the Phreatic aquifer

\section{Validation of vulnerability maps}

The relationship between the DRASTIC index and nitrate concentrations in groundwater was investigated to verify the effectiveness of the DRASTIC method. Therefore, 33 groundwater samples were collected from the wells located in the investigated areas in June 2019. The distribution of nitrate in the investigated area illustrates the concentration values ranging from 30 to $93 \mathrm{mg} / \mathrm{l}$. The highest desirable limit and maximum allowable limit of nitrate is $50 \mathrm{mg} / \mathrm{l}$ (WHO, 2011). The nitrate concentration above $50 \mathrm{mg} / \mathrm{l}$ in groundwater is harmful for human consumption. Well locations with high nitrate values are located in agricultural and built-up areas. There are no known geological sources of nitrate in the wells studied, the measured nitrate values indicate contamination of the shallow aquifer by domestic sewage infiltration under the built-up areas and excessive fertilizer use, in agricultural areas. The correlation coefficient between the DRASTIC index and the nitrate values is $\mathrm{R}=0.73$ (Fig. 10). This indicates that groundwater vulnerability mapping by DRASTIC method can be applied for reasonable management of groundwater resources and land-use in the study area.

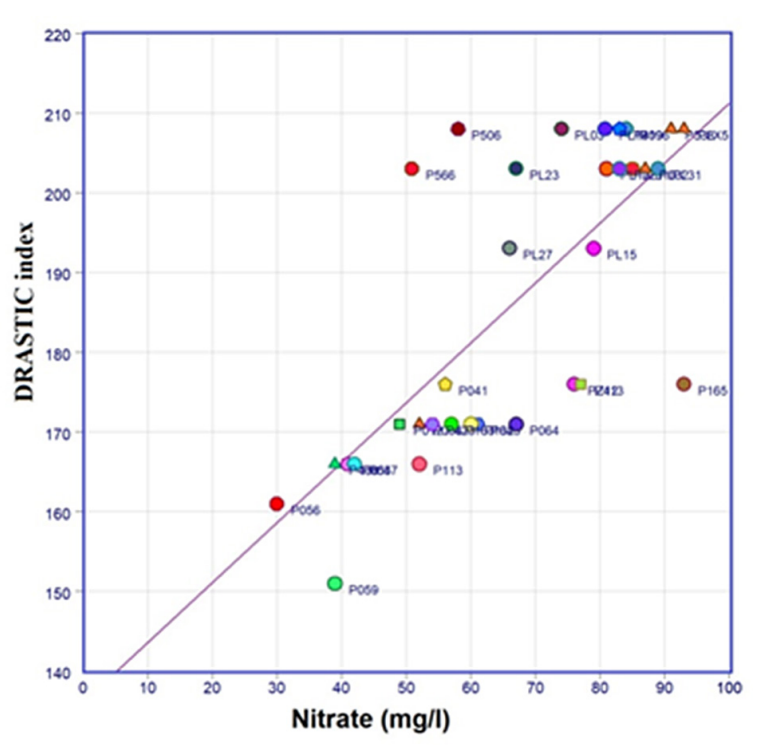

Figure 10. Correlation coefficient between DRASTIC index and nitrate concentration

\section{CONCLUSIONS}

The assessment of the vulnerability of the shallow aquifer of the Ouargla basin (Algeria Sahara) to pollution by applying the DRASTIC method reveals a trend of high to very high vulnerability to pollution. The most dominant class is the strong class $(91.6 \%)$ against $8.4 \%$ for the very strong class. The validity of the application of this method to the study of the pollution of the aquifer in question was tested by a measurement campaign of nitrates. It showed a correlation coefficient between the DRASTIC index and nitrate values $(R=0.73)$. This result indicates that DRASTIC groundwater vulnerability mapping can be applied for proper management of the groundwater resources and land-use planning in the Ouargla region.

\section{REFERENCES}

1. Al-Amoush H. Hammouri N.A. Zunic F. Salameh E. 2010. Intrinsic vulnerability assessment for the alluvial aquifer in the Northern part of Jordan Valley. Water Resour. Manag. 24 (13), 3461-3485. https:// doi.org/10.1007/s11269-010-9615-y

2. Aller L. Bennett T. Lehr J.H. Petty R.J. Hackett G. 1987. DRASTIC: a standardised system for evaluating groundwater pollution potential using hydrogeologic settings. EPA, AdA, Oklahoma. 622 p.

3. Ayed B. Jmal I. Sahal S. Bouri S. 2017. Assessment of groundwater vulnerability using a 
specific vulnerability method: Case of Maritime Djeffara shallow aquifer (Southeastern Tunisia). Arab J Geosci (2017) 10:262. DOI 10.1007/ s12517-017-3035-8

4. Bouselsal B. Kherici N. Hadj-Said S. 2015. Vulnérabilité et risque de Pollution de la nappe libre d'El-Oued (SE Algérie) : application de la Méthode DRASTIC. Bulletin du Service Géologique National., Vol. 26, $\mathrm{n}^{\circ} 1$.

5. Bouselsal B. 2017. Groundwater quality in arid regions: the case of Hassi Messaoud region (SE Algeria). J. Fundam. Appl. Sci., 2017, 9(1), 528-541. http://dx.doi.org/10.4314/jfas.v9i1.30

6. Busson G. 1970. Le Mésozoïque saharien. 2ème partie : Essai de synthèse des données des sondages algéro-tunisiens. Edit., Paris, « Centre Rech. Zones Arides» Géol., 11, 811p. Ed.

7. Engel B.A. Navulur K.C.S. Cooper B.S. Hahn L. 1996. Estimating groundwater vulnerability to nonpoint source pollution from nitrates and pesticides on a regional scale, Int. Assoc. Hydrol. Sci. Publ. 235. 521-526.

8. Fink A. 1995. How to Sample in Surveys. The Survey Kit, Volume 6. How to Sample in Surveys. The Survey Kit, Volume 6.

9. Ghazavi R. and Ebrahimi Z. 2015. Assessing Groundwater Vulnerability to Contamination in an Arid Environment Using DRASTIC and GOD Models. International Journal of Environmental Science and Technology 12 (9): 2909-18. https://doi. org/10.1007/s13762-015-0813-2.

10. Lee. S. 2003. Evaluation of waste disposal site using the DRASTIC system in southern Korea. Environ. Geol. 44, 654-664.

11. Leone A. Ripa M.N. Uricchio V. Dea J. Vargay Z. 2007. Vulnerability and risk evaluation of agricultural nitrogen pollution for Hungary's main aquifer using DRASTIC and GLEAMS models. Journal of Environmental Management 90 (2009) 2969-2978. doi:10.1016/j.jenvman.2007.08.009

12. Malik M.S and Shukla J.P. 2019. GIS modeling approach for assessment of groundwater vulnerability in parts of Tawa river catchment area, Hoshangabad, Madhya Pradesh, India. Groundwater for Sustainable Development 9. 100249. https://doi. org/10.1016/j.gsd.2019.100249

13. ONM. 2018. Bulletins mensuels de relevé des paramtres climatologiques en Algérie (période 2007-2018), Office national météorologique, Ouargla, Algérie.

14. OSS. 2003. Système Aquifère du Sahara Septentrional, gestion commune d'un bassin transfrontière, Edition Observatoire du Sahara et du Sahel.

15. Slimani R. Guendouz A. Trolard F, Moulla A.S. Hamdi-Aïssa B. Bourrié G. 2017. Identification of dominant hydrogeochemical processes for groundwaters in Algerian Sahara supported by inverse modeling of chemical and isotopic data. Hydrol Earth Syst Sci 21:1669-1691. https://doi.org/10.5194/ hess-21-1669-2017

16. Thomas A. and Tellam J.H. 2006. Modelling of recharge and pollutant fluxes to urban groundwaterS. Sc Tot Env, 360: 158-179.

17. UNESCO. 1972. Projet ERESS; Etude des Ressources en Eau du Sahara Septentrional, et rapport sur les résultats du Projet REG-100, UNESCO, Paris (1972).

18. WHO. 2011. Guidelines for Drinking-Water Quality, IVth ed. World Health Organization, Geneva, pp. 340.

19. Zeddouri A. 2008. Caractérisation hydrogéologique et hydrochimique des nappes du complexe terminal de la région de Ouargla, Thèse de Doctorat, Univ. Annaba (2008). 